\title{
The Role of Land Use Pattern and Process in the Diffusion of Valuable Tree Species
}

\author{
Jon D. Unruh \\ McGill University
}

\begin{abstract}
Evidence is mounting that conventional forestry approaches will not be able to address the extent of deforestation and land degradation underway in the tropics at the magnitude with which these problems and associated consequences presently operate. Subsistence populations for whom woody biomass and food supply is most critical can embrace many difficult and complex problems involved in the non-adoption of tree planting and tree management practices.

The occurrence of the unintentional or inadvertent spread of valuable tree species as a side-effect of certain patterns and practices involved in specific land-uses, invites examination of the functional aspects involved, and the transferability of these. This paper explores some of the concepts likely to be involved in the unintentional diffusion of valuable tree species across human-occupied landscapes under the influence of extensive land-uses in the tropics. The role of these concepts in the formulation of approaches designed to encourage this form of tree dissemination as a form of reforestation is also discussed.
\end{abstract}

Keywords: Economic trees, Diffusion, Land use, Tropics

\section{Introduction}

The permanent loss of woody biomass from tropical landscapes has the most immediate and severe impact on people in local level production systems who must deal with problems of decreasing fuelwood and food production. The deliberate planting and management of trees by local populations in the tropics will to a large degree be subject to the availability of time, energy, money, and inclination, as well as to the limited and changing priorities of development efforts in highly variable ecologic, economic, social and political environments. Subsistence populations living in precarious and high risk conditions can have very immediate needs which preclude even 
modest additional investments of time and labor into tree planting and maintenance.

Ideally the establishment of trees across a human-occupied landscape would be a by-product of the functioning of the landuse ecology itself, so that additional inputs are not required of either the local population or external entities. Such a process would have the advantage of working with the "cultural grain" to develop the "latent potentials" (Raintree 1983) within a local land-use ecology.

This paper examines the diffusion or spread of valuable tree species in a self-perpetuating manner across extensively used landscapes that exist within the sphere of influence of primarily subsistence-oriented land uses. Different from conventional reforestation, deliberately implemented agroforestry, natural tree invasion, or succession, this form of dispersion involves specific tree species or types which appear to 'fit' into existing land-uses. Such trees are able to take advantage of the opportunities for dispersal and establishment which exist within specific land use ecologies to achieve an increasing abundance of spontaneously occurring economic trees.

Drawing from a few of the examples listed in the appendix, this paper examines the salient aspects of this form of tree dissemination which might be used in approaches to encourage the dispersion of economic tree species within land-uses.

\section{Brazil}

\section{Examples}

In tropical Brazil, the babassu palm (Orbignya phalerata Mart.) as the major species, originally occupied moist bottomland sites in the climatic transition zone where the forest of the Amazon basin meets drier forest and savannas (Hecht et al 1988; Anderson et al 1987; May et al 1985; Markley 1971). This zone has come under increasing land-use pressure in the last several decades (Hecht et al 1988), and stands of babassu have followed the spread of shifting cultivation across the landscape (May et al 1985). The babassu palm is almost never planted (Hecht et al 1988). Instead the plant spreads due to land-use practices which have dispersed the plant to its present range.

The key to babassu's occupation of areas under shifting cultivation is its ability to, upon germination, push its apical meristem (or growing point) into the ground where it survives protected for several years before beginning vertical growth (Hecht et al 1988; Anderson et al 1987; May et al 1985; Markley 1971). Other palm genera also possess this form of 
germination--Attalea, Maximiliana, Scheelea, and Sabal (Anderson 1987). Thus the plant is not killed by cutting and burning as other species are, and can form monospecific stands in fallow cycles by virtue of being released from significant competition (May et al 1985; Hecht et al 1988). Anderson (1983) has reported stands as dense as 6,000 juvenile palms per hectare. Having gained a foothold in fallow sites, fire tolerance and rapid growth under a variety of light conditions assist the species in gaining dominance over a wide area. Seeds are dispersed from cleared sites by runoff and carried off by rodents--agoutis (Dasyprocta punctata) and pacas (Agouti paca) (May et al 1985). These animals are attracted to stands of babassu, and stimulate germination by removing the mesocarp (May et al 1985). Linares (1976) suggests that these animals are behaviorally preadapted to being commensals of man. At a wider scale babassu is spread long-distance by a combination of runoff, rivers, and floods (May 1985; Anderson et al 1987).

The varied utility and economic importance of babassu, especially for subsistence populations, has been well documented (Hecht et al 1988; Anderson et al 1987; May et al 1985; Markley 1971). The fruits of babassu provide an edible nut, cooking oil, lamp fuel, several different beverages, and a liquid for soapmaking, in addition to medicines, an animal feed, charcoal, flour, and insect repellent. The stems are used for construction and salt, and the palm heart provides food for humans and livestock. Leaves provide fibers, and construction materials, as well as livestock fodder, and medicine (May et al 1985 ).

As a result of its association with shifting cultivation, dense stands of babassu now cover an estimated 200,000 $\mathrm{km}^{2}$ in Brazil (May et al 1985). These palm forests comprise a critical source of products and services for hundreds and thousands of rural producers (May et al 1985; Anderson et al 1987). The oil industry from babassu kernels is the largest of its kind completely dependent on non-domesticated plants (Hecht et al 1988). And babassu charcoal provides a significant income to rural inhabitants in such magnitude as to act to protect natural forests from over-harvesting for fuelwood (Hecht et al 1988; Anderson et al 1987).

\section{Sudan}

Acacia (Acacia tortilis (Forsk.) Hayne) and mesquite (Prosopis chilensis (Molina) Stuntz) in several taxonomic forms range widely in the arid and semi-arid zones of the world. 
These trees provide an important fodder resource for both domestic and wild animals (Lamprey et al 1980; Le Houerou and Corra 1980). Ahmed (1986), working in the Sudan, has documented the spread of these species via the dominant land-use of the region--livestock grazing (also Horowitz and Salem-Murdock 1987). Domesticated stock, especially sheep and goats, act as long distance dispersers of the pods of these plants as they roam and are herded to various grazing and watering locations. The animals are attracted to the trees by the shade and the fodder. The seeds are protected from predation, particularly bruchids, by virtue of being eaten, and after defecation by residing in the droppings. Germination possibilities are increased by ingestion and pelleting in a manure-rich environment (Ahmed 1986; Horowitz and Salem-Murdock 1987). The defecated seeds are further transported to favorable (low-lying) sites by runoff and wind (due to the small mass of sheep and goat droppings) where water usually collects during rains (Ahmed $1986)$.

The importance of favorable micro-sites to the establishment of trees in desertified areas is well documented by Dixon (1989). In the example here, the frequency of seeds encountering favorable sites is enhanced because livestock are usually herded toward areas where the best water and grazing conditions can be found. Regular visitation by livestock to such areas can enhance the favorability of such sites because grazing and browsing animals are important vehicles for the transport and concentration of nutrients across landscapes and between nutrient patches (McNaughton 1979; Schwartz 1981; Senft et al 1987; Woodmansee 1979). Trees established in these sites can then act as foci for continued dispersion via animals feeding on the pods (Ahmed 1986; Horowitz and Salem-Murdock 1987 ).

The presence of forage trees on the landscape allows for increased stability of pastoral systems by allowing utilization of dry rangelands during the dry season, because the deep roots in effect makes them less dependent on current precipitation (Olsson and Rapp 1991). Utilization of tree fodder by livestock during the dry season may help to advance the spread of these trees. As livestock concentrate foraging activities more on tree fodder in the dry season (due to availability) this holds the possibility of greater dispersal of seeds via defecation. This could then create a buildup of a dry season array of seeds at the landscape scale. Such an expanse of seeds would then interact with the onset and duration of the rainy season to result in a situation where a greater number of seeds would have 
a greater possibility of being transported via runoff to the favorable sites available in areas utilized by livestock.

Acacia albida Delile is a similar example. Its original

habitat was restricted to ephemeral streams in the dry savannas of Africa. The movements of domesticated livestock however have inadvertently spread $\mathrm{A}$. albida over tens of thousands of square kilometers where it would not naturally occur (Miehe 1986; Harlan 1975; Poschen 1986). The tree does not compete with crops because it sheds its leaves and becomes dormant during the rainy season. Cultivators do not fell the tree because crop yields are frequently found to be higher in association with this species (Miehe 1986; Felker and Bandurski 1979; Radwanske and Wickens 1967; Le Houerou 1980; Unruh 1993 and the references therein). Thus this tree survives and spreads by a specific spatial and temporal combination of pastoralism and rainfed agriculture to become a dominant in certain man-made landscapes (Harlan 1975; Poschen 1986).

\section{Peru}

In the Peruvian Amazon valuable fruit trees occur in the swidden and fallow cycles of a variant of long-fallow shifting cultivation (Denevan and Padoch 1987). There is evidence that spontaneous long-term enrichment of the area with valuable trees occurs in a cyclic (swidden-fallow-swidden-fallow) fashion (Unruh 1990). Multiplication of valuable tree species in this example occurs because seeds experience favored germination and establishment due to reduced competition, enhanced fertility, nutrient input from litterfall, and reduced soil temperatures and soil moisture evaporation (Unruh 1990). The much greater frequency of suitable germination and establishment sites in and around canopy gaps are created by management practices during the fallow cycle. These interact with a spatial and temporal distribution of fruit trees which may encourage a specific optimal foraging strategy among large numbers of frugivores. The net effect of this interaction would be to decrease competition for, and increase efficiency of, seed dispersal into the larger number of available establishment sites (Unruh 1990).

\section{African savannas}

The oil palm of west Africa (Elaeis guineensis Jacq.) originally occupied forest edge conditions as it is not shade tolerant. As forests were reduced to bush fallow over many years of shifting cultivation, the palm has been saved from cutting because it is valuable, reinforced by local tradition (Harlan 1975). This species has proliferated in bush fallows 
because it is released from competition for light, and is spared by farmers when fallows are cut, burned and cultivated. Over time stands of oil palm have become thicker, and in some regions very extensive stands have developed without any planting (Harlan 1975). In addition the fruits of the oil palm are borne in large bunches which are cut and beaten off the bunch in the bush away from the villages, assisting in the inadvertent spread of the species (Harlan 1975).

The baobab (Adansonia digitata L.) tree is also widely distributed throughout the savannas of Africa, as well as in south Asia and northern Australia (Harlan 1975). This tree can become quite large and is useful in a variety of ways. The fruit is consumed, the bark provides fiber, the leaves make good pot-herbs, and the hollow boles form cisterns which collect water from the rains and store it for long periods of time (Harlan 1975; Hartwig 1872). In Africa the close association between stands of baobab trees and village sites has been noted in both historical (Hartwig 1872) and current texts (Harlan 1975). Harlan (1975) suggests that such stands develop as fruits are repeatedly brought to a village. As new seedlings become accidentally established, they are recognized as valuable and not cut.

\section{Central America}

In areas of lowland Yucatan previously inhabited by the Maya and subsequently occupied by their descendants in a shifting cultivation land-use, numerous investigators have observed a present-day forest distribution of useful tree species known to have been exploited by the Maya (Barrera et al 1977; Folan et al 1979; Lundell 1937; Puleston 1978; Netting 1977; Cook 1909; Gordon 1982). That many economic species used by the Maya are now secondary successional species presently found in fallow plots (Turner and Miksicek 1984; Folan et al 1979) is evidence that useful trees, having gained a foothold in an area due to human alteration of a landscape (high frequency of secondary sites) are able to continue a significant presence in the area in association with shifting agriculture (Unruh 1990). Some of these include: mamey (Calocarpum mammosum (L.) Pierre), chicle (Achras zapota L.), guayo (Talisia olivaeformis (H.B.K.) Radlk.), and custard apple (Annona reticulata L.) and ramon (Brosimum alicastrum Swartz) (Lundell $\overline{1938 ; ~ B u d o w s k i ~ 1959 ; ~}$ Peters 1982; Alcorn 1981).

Ramon deserves particular mention. The tree exists in almost pure stands in the northeast part of its range, but due 
to its widespread pre-Hispanic use it is not known if these concentrated stands are the result of ancient land-use practices, or occur naturally (Peters 1982). The species' ability to be an extremely aggressive colonizer on disturbed sites (Peters 1982) ie., cleared for agriculture, have led some to speculate that it is even preadapted to such sites (Miksicek et al 1981). In any case the plant does colonize sites altered by man, and this together with heavy dispersal by frugivorous bats which also favor such areas (Palmeirim and Etheridge 1985; Fleming et al 1977) enables the tree to encounter greater success in locating favorable establishment sites, which exist in greater numbers in areas occupied by man.

While succession does play a role in these examples, the frequency of secondary sites is controlled by humans, and is what enables these species to exist in the abundance they do. Thus, it is the combination of land use and ecology which results in the presence of these trees on human occupied landscapes. Neither succession or land use alone would be able to achieve the same presence.

\section{Sacred and semi-sacred trees}

There exist a host of trees which have sacred value to various societies for which the end result is nearly the same; the trees are spared and protected, and thereby released from competition as land is repeatedly cleared for agriculture or firewood. As a result these species take advantage of established sites created by humans to become dispersed over large areas. The karite (Butyrospermum paradoxum (Gaertn.) Hepper) of west Africa is one example. Although an edible oil is extracted from the fruit, the tree owes its protection from the fact that it is regarded as a semi-sacred tree. As a result, very large areas of the broadleaved savanna in west Africa are covered with almost monospecific stands of karite (Harlan 1975). Similar situations exist for the pippul (Ficus religiosa L.) in India, and for the combination or "marriage" of pippul and palmyra (Borassus aethiopium Mart.) in India and Ceylon. As well, various species of palm on islands in the Indian Ocean, date trees of north Africa and the Middle East (Hartwig 1872), and ceiba in Africa (Lathrap 1977), owe their present distribution to their status within certain societies.

Such examples, while important to specific cultural groups, do have implication for revegetation on a wider scale. They all illustrate the importance of traditional knowledge and customs which themselves present opportunities for development of the landscape. Such cultural aspects however are only valid as long 
as groups survive in ways that are internally cohesive. Sacred and semi-sacred plants underscore one of the many values of encouraging and allowing traditional groups faced with change from external forces--as almost all are today--to manage change in a way which engages, instead of eliminates, traditional practices, knowledge and beliefs.

\section{Theoretical Aspects}

What the examples above and those included in the appendix illustrate, is that the fortuitous spread of valuable trees can and does occur over large areas as a result of the interaction between land use and ecological process. How this occurs bears some resemblance to processes noted by those who have studied the origin and spread of agriculture.

\section{Weediness and the origin of agriculture}

Several authors investigating the emergence of agriculture have noted that the initial casual association of plants with humans has often been the basis for the plant-man symbiosis involving both the domestication of plants, and parasitic associations (weediness) (Rindos 1980; Harris 1972; Harlan 1975). However "one man's weed can be another man's crop " (Harlan 1975). Harlan (1975) provides a compelling treatment of the intermediate states between crop and weed, outlining two conditions regarding these: the ecological behavior of the plant in question, and man's response to the plant. Neither condition is clear-cut or distinct, and many gradations exist between extremes. Such gradations might operate as Harlan (1975) suggests, summarized here in Figure 1. What this figure broadly illustrates is that a continum exists between cultivated, noncultivated, and weedy states. A number of authors have noted the fluidity of plants labeled domesticate, nondomesticate, and weedy, especially in the tropics (Alcorn 1981, 1983; Posey 1985; Denevan and Padoch 1987).

The trees and processes of interest here exist within such intermediate states. These species are neither completely domesticated or completely weedy. They are present on human occupied landscapes as a result of the processes involved in both domestication and weediness. Because the trees are valuable they may (or not) be dealt with in favorable ways ranging from being spared when other vegetation is cut, to purposefully encouraged. At the same time these species are able to take advantage of certain land uses to disperse themselves. Figure 1 is of course a very crude depiction of the gradations and elasticity of intermediate states in reality. 
The interface between ecology and land-use which results in the distribution of a tree species across a landscape is more complicated than an interface which results in no trees remaining on a landscape.

In general the development of agriculture has been a process whereby the ecosystem decreases in complexity and the sociosystem increases in complexity relative to the ecosystem (Norgaard 1981). Thus the possibilities for successful tree proliferation will be different at different points along this pathway of changing complexities.

\section{Temporal, spatial, and cultural windows of opportunity}

Requisite to the processes of domestication and weediness is the exposure of the plant in question to a specific land use. For a tree species, exactly how this association occurs is fundamental to its success. Some trees might have been relatively uncommon prior to human impact on the landscape. However the combination of certain land-use(s), at a particular intensity, which results in a distinct sociosystem - ecosystem 'state' of a landscape, together with the ecological behavior of the plant, and then man's response to the plant, can result in the expansion of a species' ecological niche. A plant and landuse which are able to take advantage of such windows of opportunity must be connected in time, exist in proximity, and in the proper cultural context in the course of human-induced development of the landscape. These three dimensions--temporal, spatial, and cultural--can encompass each other and are

responsible for the occurrence, or not, of opportunities for the diffusion of tree species within land uses.

For the temporal dimension it is possible that tree species which disappeared in earlier stages of a land use history might have encountered an opportunity for proliferation at a later stage. But such an interaction does not take place because the proper land-use phase and species did not occur concurrently. Land-use ecology over time embraces an enormous number of stages and types of environment (Bowman 1924) as specific groups respond to changing situations (Alcorn 1981a). The consequences of historical human responses to the environment may preclude subsequent realization of opportunities, both ecological niche opportunities and utilization opportunities.

Trees by their nature take a relatively long time to grow, and some species take quite a long time to produce a useful item. The time that it takes to both grow and produce must fit well with the land-use, if the tree is going to be able to multiply itself within the land-use. Such a fit must also be 
able to exist given the direction of land-use change. If for example fallow periods are becoming shorter, this may eliminate opportunities for some and create opportunities for other instances of tree dissemination to occur. The lontar palm (Borassus flabellifer L.) in Southeast Asia is an example of a plant that is able to take advantages of shortening fallow periods and degrading agricultural fields.

Some tree species are themselves able to affect the development of land-use over time. The litter and branch-fall from babassu, is such that significant nutrients are added to the soil, allowing the fallow period to shorten without loss of agricultural production (Hecht 1988). The ability of the baobab tree to store large amounts of water has led them to be seen as an asset and swidden fields in the western sudan are frequently located near the trees (Abdul 1987). The fallow period in these fields is dominated by the gum tree (Acacia senegal (L.)

Willd.), forming dense 'gum gardens' (Jackson and Shawke 1950; Seif el Din 1969). Thus farmers who owned baobab trees had better chances of acquiring gum gardens (Abdul 1987). This is an example of a tree involved in diffusion via land use (baobab) promoting the opportunity for another tree to multiply (gum). With increasing importance of the gum trade, some land owners in central Kordofan have made use of landless farmers to create new gum fields. These farmers were allowed to cultivate land until it was exhausted, whereupon it was returned to the owner with a growing thicket of gum trees (Abdul 1987). In this case the fortuitous occurrence of baobab and then acacia in association with tenant rainfed agriculture, and the increasing marketability of gum, plays a very influential role in the development of land use.

For the spatial dimension, plant species and land-uses occupying spatially distinct and unconnected locations can constitute unrealized opportunities. It is possible that if two or more specific land-uses occur in close proximity, or in the same location, or in a specific sequence relative to each other, certain opportunities of tree species diffusion might exist. This becomes more involved when considered as functioning together with the temporal dimension.

The dimension involving human culture, or knowledge and values is perhaps the least straightforward, but can be the context for the temporal and spatial dimensions. The flow of knowledge about plant life and human organization (Bowman 1924) which allows recognition and utilization of plants can be disjointed spatially and temporally. Knowledge or ignorance about the attributes of specific tree species at a given point 
in time may interact favorably or unfavorably in man's dealing with the plant so that opportunities for proliferation are gained or lost.

The organization, values, and capabilities of the groups involved are important as well. Similar opportunities for propagation of trees for societies with similar capabilities might be realized for one group and shunned by another due to a difference in values, tenure regime, or power structure. As well groups with similar values might respond to such opportunities differently due to differences in capabilities. The permutations involving these three dimensions--temporal, spatial, and cultural--result in different sets of interactive possibilities to either allow or disallow various opportunities for the expansion of trees into new land use niches.

The Acacia albida example is illustrative. This tree has spread over extensive areas of the African savanna because two land-uses, pastoralism and rainfed agriculture operate together to facilitate the spread and protection of the tree. Due to its own ecology the tree does not have foliage at the time crops are growing, thus eliciting a human response not to remove the plant. Had such a tree never existed in the region, or had the tree disappeared from its original habitat through deforestation before pastoralism had acted to spread it, or had pastoralism not occurred in the way it did at the time it did, or in the intensity it did, the tree would likely not exist in its present range. Once out of its initial habitat, rainfed agriculture--of a specific population density and set of agricultural practices, together with a population that was knowledgeable about, or became knowledgeable about the value of the tree--acted to spare the tree, promoting its distribution across the savanna.

Building on these concepts then, the question perhaps is, what "latent potentials" (Raintree 1983) might exist for tree expansion to occur in conjunction with certain land-uses? What opportunities did not occur due to the non-synchronization of the various aspects involved? And ultimately, what opportunities might be deliberately encouraged?

\section{Landscape Scale Pattern and Process}

There are a number of constructs of tree dissemination operating within the above mentioned dimensions which further allow or disallow tree diffusion at the landscape scale. This section attempts to define some of these in order to attempt a framework within which variations of such dissemination might be examined. 


\section{Landscape connectivity and opportunity patches}

Turner (1989) regards the landscape as a mosaic of habitat patches of a dynamic set of sizes, frequencies and distribution specific to particular plant species. These patches are interconnected in terms of a dispersal "potential" in a way again specific to the species in question. This "connectivity" (Turner 1989) or degree of ease of dispersal, in a human altered landscape results from the operating interconnections between the sociosystem and the ecosystem.

For intermediate state trees the existing set of habitat patches in a landscape together with a high degree of connectivity result in a set of 'opportunity patches' for a specific tree species to become established within. Habitat patches may be abundant over a landscape but unless they are connected to other patches and to a seed source in a way that allows significant dispersal (embracing the necessary time and distance requirements), they cannot be considered opportunity patches for the tree. Connectivity between patches may be governed by a combination of patch structure at different scales, landscape resistance (barriers) (Van Dorp and Opdam 1987) as well as dispersal processes and vehicles for dispersal; all of which result in a given dispersal 'flow'. Several authors have investigated the nature of such connectivity for various network configurations and degrees of habitat isolation (Henderson et al 1985; Fahrig and Merriam 1985; Milne et al 1989; MacClintock and Whitcomb 1977).

Likewise connectivity may be high for a landscape, but unless there also exists a set of habitat patches that corresponds with the character of the existing connectivity, opportunity patches will be absent. However, even opportunity patches and connectivities can exist in gradients. The degree of connectivity and patch structure can result in a spectrum of opportunity patch possibilities of varying potential. The range of what constitutes a 'high potential' opportunity patch for a given tree species may be narrow or wide, will differ with each land-use, and will be largely dependent on how well the degree of connectivity and structure of habitat patches agree for a specific tree species within a given land use. While the requirements for a habitat patch may be static and biophysical, connectivity can be more dynamic. Connectivity for a particular species can focus more heavily on the ecosystem, the sociosystem, or in varying degrees a combination of the two. The focus of this reliance can change over time, as the land-use ecology itself changes. 
Regardless of the focus of connectivity for a species, the minimal requirement for connectivity to operate is that a seed or vehicle for seed transport be able to move across the landscape in a path of length $\underline{n}$ with a certain probability of locating a resource (Turner 1989). The path length will vary with the tree species and/or transport vehicle as well as patch structure. If the probability of encounter of opportunity patches is low, and/or the occurrence of patches takes place at lengths greater than $\underline{n}$ at high frequency for a given species, then the resulting distribution of the species across the landscape will be minimal or non-existent.

Modifications in land-use will result in changes in habitat connectivity and opportunity patch structure that can both eliminate and create opportunities for tree replication at different stages of a modification. Changes such as land degradation, intensification of agricultural practices, adoption of new or abandonment of old practices, population increase, changing market arrangements, changes in tenure, and so forth all bring about alterations in the nature of patch structure and connectivity.

For the deliberate creation of opportunities for, or encouragement of, tree multiplication, the trick will be in spotting opportunities which exist for diffusion within existing, or introduced landscape connectivities and patch structure for a given land use.

\section{Cultural constructs}

Preferences, perception, and recognition

The role of long standing, traditional cultural attitudes and preferences in the use of the environment can be profound. Preferences for regarding specific plants and animals in specific ways in established land-use patterns, are major factors in the functioning and potential development of the landscape (Simoons 1960; Salem-Murdock 1979; Lado 1989; Bohle et al 1991; Apthorpe 1968). Such attitudes--often rooted in history--allow the development of certain possibilities of the environment and ignore or reject others (Simoons 1960; SalemMurdock 1979).

In a variety of ways local recognition of a tree species as valuable and able to fill a perceived need can promote replication of the species. Alcorn (1981a 1981b) explains the complicated nature of plant "resource perception" in which the "process of assigning a particular resource role, or 'use' to a plant [is accomplished] by evaluating that plant's possible utility and the consequences of using it". That such perceived 
'needs' and 'uses' encompass much more than simply consideration of the physical properties of plants which fill standard human needs emphasizes the importance of the "contextually related/ dependent" circumstances within which plant recognition and use occur (Alcorn 1981b). The interpretation of 'use' as a behavioral response (Hays 1974) has application to the definition of tree diffusion used here, since this response will act to either encourage or discourage the distribution of a tree species across the landscape. And while needs and uses surrounding plant utilization must answer present day land use strategies, these are influenced by historical strategies and trends of resource use from which present day perceptions develop (Alcorn 1981b; Simoons 1960).

Risk and tenure Sociosystem recognition of tree species as valuable and thus worthy of protection, may occur most often in situations where risk avoidance with the least labor investment are priorities (Alcorn 1981). This would include subsistence production systems on marginal lands where risks of production failure are high. Such lands can offer the basic conditions that favor quick and widespread recognition of tree value. Inhabitants of arid, stony, or steep terrain, areas of low fertility and scarce fuelwood, fodder, and agricultural land, along with regions of high unemployment, tenure insecurity and recurring drought and famine, may be the quickest to recognize and encourage openings for the multiplication of valuable tree species. Such situations are also where agroforestry adoption rates are highest for many of the same reasons (Alcorn 1981; Mol 1989; Winterbottom and Hazlewood 1987; Young 1988).

Tree tenure may play a significant role in the recognition of tree species as valuable and worth protection. If use of a valuable tree or trees which occur spontaneously implies recognized ownership (Raintree 1987), then this can mean protection. Such an arrangement can encourage others in the community to claim and protect other trees of the same species as their own; expanding sociosystem recognition of the species as valuable and worth protection. This has been documented for gum arabic (Acacia senegal) in the Sudan (Abdul 1987). If such protection involves, as it often does, not cutting down the plant itself, and instead cutting away competing nearby plants and preventing use/over-use of the tree by others in the community, as well as preventing destruction by livestock, wildlife, etc., then this ensures the survival of trees that would not have remained otherwise. This then enhances the 
ability of the tree to produce more seeds.

Heterogeneity and complementarity

The degree of heterogeneity and complementarity involving distinct cultural patterns can exert influences on the spread of tree species. Both operate at varying scales and have varying influences on the ability of tree species to occupy new areas. High sociosystem heterogeneity in a relatively small area with few significant interdependencies will most likely inhibit the spread of tree species via specific land-uses and combinations of land-uses; confining such examples of replication as they do exist to small areas. The iterative increase of economic tree species in the Peruvian Amazon (Unruh 1990) is such a case. Large scale examples of replication in such a culturally heterogeneous context will rely far more heavily on the ecosystem for replication instead of the sociosystem. Babassu in the Amazon is an example of this.

Large areas covered by the same or similar land-uses on the other hand can be receptive to single examples of tree replication. The spread of mesquite in arid and semi-arid North America (Grover and Musick 1990) and acacia in south-central Africa (van Vegten 1983; Skarpe 1990) where extensive livestock grazing is the dominant if not exclusive land-use illustrates this. Such areas have low sociosystem heterogeneity, and thus tree dissemination over a large area is not dependent on or subject to interdependencies between distinct cultural patterns and land-uses. Such examples can frequently rely more heavily on the sociosystem than the ecosystem for replication. Thus where grazing is excluded, mesquite and acacia do not occur at the scale it does where grazing is permitted. Livestock (cultural factor) are especially effective vectors of seed dispersal, because they consume large quantities of fruit, travel relatively long distances, and deposit large numbers of intact seeds in dung. They also act to significantly reduce grass competition (Brown and Archer 1987; Archer et al 1988; Skarpe 1990). Archer et al (1988) note that although prelivestock native herbivores and granivores such as deer, bison, and rodents were native dispersers of mesquite, few propagules became established in grasslands by them. Instead mesquite was restricted to drainageways, occurring elsewhere only in association with old Indian campsites (Grover and Musick 1990).

As an aside, the spread of mesquite in North America has generally been viewed as a detriment to productive grazing (Grover and Musick 1990; Brown 1950). However, the species is viewed as a very valuable multipurpose plant in other parts of 
16

the world, and there is recent evidence that mesquite has been underutilized in its North American range (Martin 1985; Almanza and Moya 1986; Arya et al 1991).

\section{Thresholds and positive feedbacks}

Sociosystem thresholds

As valuable trees become established within land-uses, there are thresholds beyond which certain feedbacks can be engaged, magnifying the process of diffusion. In the fallow cycle of the Peru example, if only a few valuable trees have become established in a fallow of otherwise non-useful plants, the fallow will be a candidate for clearing once a new field is needed. If however there are a large number of valuable plants in the fallow, the site will not be cut because it produces enough of a valuable commodity or service so as to be worth sparing. Either another site will be chosen or the valuable trees will be left standing and crops planted underneath (Unruh 1988). As a result many more trees will be available to act as source locations for the continued dispersion of the species (Unruh 1990). At a larger scale, as the numbers of valuable trees become more frequent in an area, its uses become both more widely known, and often more uses are found. As a result the tree is given greater and more widespread recognition and afforded greater protection.

At yet a larger scale as recognition and awareness grows, market opportunities may surface promoting still more widespread protection and encouragement of the tree. This has been the case with babassu in Brazil (Anderson 1987), sago palm (Metroxylon sagu Rottb.) in southeast Asia (Ellen 1979), gum arabic (Acacia senegal) in the Sudan (Abdul 1987), and cocoa in west Africa (Theobroma cacao L.) (Berry 1975). For some species, large numbers would have to be present before such broad recognition of the plant would occur.

Ecosystem thresholds

Other thresholds and feedbacks may exist within the ecosystem. While the spread of first mesquite and then other woody species in North America, is due to overgrazing and seed dissemination by cattle, individual and widely scattered mesquite plants produce fewer seeds than individuals in a group. Isolated plants are preyed upon by rodents and rabbits, and trampled by large animals, stimulating vegetative regrowth but decreasing seed production and seed dispersal (Valentine and Gerard 1968; Wallace and Romney 1972; Campbell 1929). Consequently the more mesquite plants present in an area the 
more fruits are produced which then interact with the dispersal mechanisms provided by cattle, sheep, horses, antelope, rodents, rabbits, and birds (Parker and Martin 1952; Glendening and Paulsen 1955; Campbell 1929; Archer et al 1988). Thus, greater numbers of trees means more seed production per plant and more seed dispersal, providing a feedback for a greater number of trees.

With increasing presence of mesquite, avifauna that frequent wooded habitats can be attracted to the plants, which then become recruitment foci for the bird-dissemination of woody plants that normally occupy other habitats (Archer et al 1988). Grover and Musick (1990) and Archer et al (1988) detail a number of other edaphic and biotic feedbacks favoring the establishment of mesquite at the landscape scale once a sufficient number have become established. Most of these surround effects by mesquite itself and associated dispersers to further decrease competition with grasses, and increase dispersal and potential establishment sites.

Similar feedbacks exist for other examples. However detailing these would require considerable text, and the purpose here is illustrative.

Faunal assemblages

Land-use or culturally specific faunal assemblages can be very important not only in seed dispersal, but in their role in feedbacks which favor tree establishment. Such assemblages in man-altered environments can depart radically from their numbers and relative proportions in natural habitats (Palmeirim and Etheridge 1985; Linares 1976; Tuttle 1976; Fleming et al 1977). Linares (1976) observes that the percentage of agouti, paca, and armadillo (the first two being very important fruit tree seed dispersers) in association with shifting agriculture practices in Panama is three and four times that observed in natural forests of Barro Colorado Island and Surinam, respectively. The role of faunal assemblages in tree seed dispersal deserves particular mention here because in tropical forests a large proportion of tree species (often 75\% or more) produce fleshy fruits adapted for faunal consumption (Howe and Smallwood 1982).

The structure and distribution of valuable trees can induce a change in the foraging activities of faunal assemblages which are attracted to these sites. Such a change may result in a more efficient dispersal of seeds to adequate germination sites. Fleming et al (1977) note that the foraging behavior of frugivorous bats for example is highly responsive to the spatiotemporal differences in distribution patterns of fruit trees, as 
Johns (1988) does for other frugivores. Because foraging operates within the constraints of an energetic balance of costs and benefits (Hamilton and Watt 1970; Schoener 1969) foraging strategies tend to optimize energetic return per unit of effort and time expended (Fleming et 1977). Thus the temporal and spatial distribution of fruit trees determine the foraging strategy used in order to maximize the number of fruit trees encountered; thereby maximizing dispersal of the plant as well.

For example when fruit trees are evenly distributed throughout the forest, the optimal strategy is to commute and search simultaneously. When food resources are clumped in patches however (as in fallows) the optimal strategy is to first commute to the food resource and then search for food, as there is little return from searching for food between known clumps of fruit trees (Fleming et al 1977). Thus fruit trees which occur together would not casually attract the frugivores necessary for dispersal, but would fit into an optimal mode of foraging behavior; decreasing competition for frugivores by fruit trees, and enhancing dissemination.

The behavior of faunal assemblages can be influenced in other ways by human-altered landscapes. Again for bats, nightly movements are typically made along well travelled flyways which include man-made trails (Palmeirim and Etheridge 1985; Tuttle 1976; Fleming et al 1977) that are especially common in areas of shifting cultivation. Posey (1985) estimated that there were approximately $500 \mathrm{~km}$ of trails an average of $2.5 \mathrm{~m}$ wide in the proximity of one of the Amazonian villages included in his study.

The use of trails by bats during nightly foraging influences their flight patterns and effects seed dispersal because bats drop seeds while commuting (Palmeirim and Etheridge 1985). This creates bat generated seed shadows along man-made trails (Palmeirim and Etheridge 1985). Several studies have described the different characteristics of frugivore generated seed shadows (Janzen 1970; 1971; et al 1976; Fleming and Heithaus 1981; Smith 1975; McDonnell and Stiles 1983). Thomas et al (1988) highlight the importance of the interaction between seed shadows generated by birds and bats and the availability of "safe sites" for germination and survival of seeds.

The eventual development of such assemblages (signifying a threshold crossed) as a function of specific land-uses, presents opportunities for positive feedbacks to operate. While such opportunities can be difficult to foresee, and the mechanisms behind plant dispersal by fauna are not completely known (Howe and Smallwood 1982), their ultimate effect can be quite 
important.

\section{Approaches for Encouraging Land Use Dispersion of Tree Species \\ Barriers and latent opportunities}

In order to initiate the dispersal of valuable trees within existing land-uses, two approaches might be possible. One would be to identify and investigate the barriers or constraints that exist within prevailing sociosystems and ecosystems for a desired connectivity and opportunity patch structure to occur for a particular tree species; together with an assessment of the possibilities for altering those barriers. The other approach might be to investigate which tree species would be able to take advantage of the connectivities and opportunity patch structure already present (or latent) in the existing land-use.

Which approach to chose in which situation will no doubt differ with varying biophysical, cultural, and land-use contexts. Some things will be easier to change than others, and this will influence the approach. An example involving barriers exists in Niger, where a development project constructed small earthen structures (earth banks, stone lines, rock dams, etc.) to divert flash floods from gullies onto slopes (Harrison 1987). As a side effect these structures collected soil, leaves, and seeds, and local tree species appeared on their own (Harrison 1987). These trees then act as sources for subsequent dispersal. In this case the barrier was that the connectivity in place did not coincide with the frequency and distribution of potential opportunity patches for local tree species. By creating patches of a distribution equal to or less than length $\underline{\mathrm{n}}$ required for the existing connectivity, the spread of trees was initiated. Depending on the situation it is possible that only a small number of well placed opportunity patches might be needed to attach an in-place connectivity to existing patches of a distribution greater than length $\underline{\mathrm{n}}$.

An example illustrating the approach focusing on specific tree species is the spread of neem (Azadirachta indica) in the Sahel. This tree was introduced into Senegal, Mali, and the Sudan earlier this century and has since spread the length and breadth of the Sahel (Taylor and Soumare 1983). Today neem is one of the more common species of the region, especially around areas of human habitation (Taylor and Soumare 1983). While the tree is quite compatible with local land uses, birds and bats are presently spreading the seeds allowing natural regeneration of the tree to occur (Taylor and Soumare 1983). In this case 
the tree species was able to take advantage of connectivities and opportunity patch structure that were, up until the time of introduction, latent within the resident land-use ecologies of the Sahel, but unused by local plant species.

Measurement and prediction of the potential diffusion of valuable tree species within and among land uses could be approached using the large number of applicable spatial diffusion models currently employed by geographers and others (Morrill et al 1988). New diffusion models are being developed all the time, such that to tailor or derive a model to suit the type of diffusion described here, or even to fit specific examples, might be fairly straightforward. However, derivation of such a model is beyond the scope of this paper. But perhaps a more difficult consideration will be to understand and then define how connectivity and opportunity patch structure operate temporally, spatially, and culturally for specific land uses, and the requirements for these, for specific tree species.

This paper does not claim to define all aspects of the type of tree diffusion outlined here. What it attempts is a cursory exploration into some of the concepts likely to be involved. The research needed to gain a greater a understanding of the real potential of land use based tree dispersion involves the development of a knowledge base which integrates the cultural and biophysical aspects of individual plant species on the one hand, and concepts of landscape scale process and pattern on the other.

For the topic described here (as well as others), the application of ethnobotanical knowledge within tropical production systems can hold considerable promise in implementing effective, lasting rural development interventions for populations engaged in increasingly precarious subsistence on increasingly marginal land resources.

\section{Bibliography}

Abdul G.S.el.D. Gum hashab and land tenure in Western Sudan. In: Raintree JB (ed.) Land, Trees and Tenure, ICRAF and the Land Tenure Center, Nairobi and Madison; 1987: 217224.

Ahmed el Houri Ahmed. Some aspects of dry land afforestation in the Sudan with special reference to Acacia tortilis and other species. Forest Ecology and Management; 1986; 16: 209221. 
21

Alcorn JB. Huastec noncrop resource management: implications for prehistoric rainforest management. Human Ecology; 1981;

9:395417.

Almanza SG, Moya EG. The uses of Mesquite (Prosopis spp.) in the highlands of San Luis Potosi, Mexico. Forest Ecology and Management; 1986; 16: 4956.

Anderson AB. The biology of Orbignya martiana (Palmae): a tropical cry forest dominant in Brazil. Ph.D. Dissertation, Dept. of Botany, University of Florida, Gainesville; 1983.

Anderson AB, Anderson ES, Ewel JJ. People of the palm forest: biology and utilization of babassu forests in Maranhao, Brazil. In: Lugo AE, Hecht SB, Murphy PG, Padoch C, Schmink MC, Stone D (eds.) People and the Tropical Forest; 1987; MAB Research Report.

Anderson AB. Management of native palm forests: a comparison of case studies in Indonesia and Brazil. In: Gholz HL (ed.) Agroforestry: Realities, Possibilities, and Potentials. Martinus Nijhoff Publishers and ICRAF, Dordrecht; 1987.

Archer S, Scifres C, Bassham CR, Maggio R. Autogenic succession in a subtropical savanna: conversion of grassland to thorn woodland. Ecological Monographs; 1988; 2: 111127.

Barbor KM. The Republic of the Sudan. University of London Press Ltd., London; 1961.

Barrera A, GomezPompa A, VazquezYanes C. El manejo de las selvas por los Mayas: sus implicaciones silvicolas y agricolas. Biotica; 1977; 2: 4761.

Berry SS. Cocoa, Custom and Socioeconomic Change in Rural West Nigeria. Oxford, UK: Claredon Press; 1975.

Bohle HG, Cannon T, Hugo G, Ibrahim FN (eds.). Famine and Food Security in Africa and Asia: Indigenous Response and External Intervantion to Avoid Hunger. Bayreuth: Verlag; 1991.

Bowman I. The Andes of Southern Peru. Henery Holt and Company, New York; 1916. 
Bowman I. Desert Trails of Atacama. American Geographical Society, Special Publication No. 5; New York; 1924.

Brown AL. Shrub invasion of southern Arizonia desert grassland. Journal of Range Management; 1950; 3: 172177.

Brown JR, Archer S. Woody plant seed dispersal and gap formation in a North American subtropical savanna woodland: the role of domestic herbivores. Vegetatio; 1987.

Budowski G. Algunas relaciones entre la presente vegetacion y anitguas actvivdades del hombre en el tropico americano. Actas del XXXIII Congreso Internacional de Americanistas, San Jose, Costa Rica Vol 1; 1959.

Campbell RS. Vegetative succession in the Prosopis sand dunes of southern New Mexico. Ecology; 1929; 10(4): 392398.

Cook OF. Vegetation afffected by agriculture in Central America. Plant Industry Bulletin 145, Washington, D.C., USDA; 1909.

Denevan WM, Padoch C (eds.). SwiddenFallow Agroforestry in the Peruvian Amazon. New York: The New York Botanical Garden; 1987 .

Dixon RM. Land imprinting for dryland revegetation and restoration. In: Berger JJ (ed.) Environmental Resortation: Science and Strategies for Restoring the Earth. Island Press, Washington, D.C. 1989.

Ellen RF. Sago subsistence and the trade in spices: a provisional model of ecological succession and imbalance in Moluccan history. In: Burnham PC, Ellen RF (eds.) Social and Ecological Systems. Academic Press, London, 1979.

Ellis G. Issues in African energy development: on teaching how to fish... In: Proceedings of Workshop on Energy, Forestry, and Environment; 1982: Bureau for Africa, USAID.

Emslie SD. Birds and prehistoric agriculture: the New Mexican Pueblos. Human Ecology. 9: 305-329; 1981.

Fahrig L, Merriam G. Habitat patch connectivity and population survival. Ecology; 1985; 66: 17621768. 
Felker $\mathrm{P}$, Bandurski R. Uses and potential uses of leguminous trees for minimal energy imput agriculture. Economic Botany; 1979; 33: 172184 .

Fleming TH, Heithaus ER, Sawyer WB. An experimental analysis of the food location behavior of frugivorous bats. Ecology; 1977 ; 58: 619627 .

Fleming TH, Heithaus ER. Frugivorous bats, seed shadows, and the structure of tropical forests. Biotropica; 1981; 13: 4553.

Folan WJ, Fletcher LA, Kintz ER. Fruit, fiber, bark and resin: social organization of a Maya urban center. Science; 1979; 204: 697701 .

Fox JJ. Harvest of the Palm. London: Havard University Press; 1977 .

Glendening GE; Paulsen HE. Reproduction and establishment of Velvet Mesquite as related to invasion of semidesert grasslands. Forest Service, USDA Tech Bull 1127 Washington D.C. ; 1955 .

Grover HD; Musick HB. Shrubland encroachment in southern New Mexico, U.S.A.: an analysis of desertification processes in the American southwest. Climatic Change; 1990; 17: 305330.

Hamilton JW; Watt $\mathrm{KEF}$. Refuging. Annual Review of Ecology and Systematics; 1970; 1: 263286.

Harlan, JR. Crops and Man. Madison, Wisconsin: American Society of Agronomy, Madison, Wisconsin; 1975: pp. 6496.

Harris DR. The origins of agriculture in the tropics. American Scientist; 1972: 180193.

Harrison MN; Jackson JK. Ecological classification of the vegetation of the Sudan. Forests Bulletin. no. 2, Forest Department, Khartoum, Sudan; 1958.

Harrison P. Trees for Africa. New Scientist; 1987; May 14: 5457.

Hartwig G. The Polar and Tropical worlds: A Description of Man and Nature in the Polar and Tropical Regions of the globe. Springfield, MA, USA: Bill, Nichols and Co.; 1872. 
Hays TE. Manua: Explorations in Ndumba ethnobotany. Unpublished Ph.D. Dissertation. Unversity of Washington, Seattle; 1974.

Heathcote RL. The Arid Lands: Their Use and Abuse. London: Longman; 1983.

Hecht SB, Anderson AB, May P. The subsidy from nature: shifting cultivation, successional palm forests and rural development. Human Organization; 1988; 47.

Henderson MT, Merriam G, Wegner J. Patchy environments and species survival: chipmunks in an agricultural mosaic. Biological Conservation; 1985; 31: 95105. Horgan P. Great River: the Rio Grande in North American History. Rinehart and company, New York; 1954.

Horowitz MM; Salem-Murdock M. The political economy of desertification in White Nile Province, Sudan. In: Lands at Risk in the Third World: Local Level Perspectives, Little PD, Horowitz MM, Nyerges E (eds); 1987; Westview Press, London: pp. 95143.

Houerou le LE. Agrofrestry techniques for the conservation and improvement of soil fertility in semi-arid zones. In: Houerou le LE (ed.) Browse in Africa. ILCA, Addis Ababa; 1980.

Howe HF; Primack RB. Differential seed dispersal by birds of the tree Casearia nitida (Flacouriaceae). Biotropica; 1975; 7: 278283 .

Howe HF, and Smallwood J. Ecology of seed dispersal. Annual Review of Ecology and Systematics; 1982; 13: 201-228.

Ibrahim FN. Ecology and land use changes in the semiarid zone of the Sudan. In: Little PD, Horowitz AE, Nyerges AE (eds.) Lands at Risk in the Third World: Local Level Persectives. London: Westview Press; 1987.

International Center for Research in Agroforestry (ICRAF). Agroforestry Systems Inventory Database; Nariobi; 1989.

Jackson JK; Shawke MK. Shifting cultivation in the Sudan. Forestry Department Memorandum No. 2; 1950. 
Janzen DH. Herbivores and the number of tree species in tropical forests. America Naturalist; 1970; 104: 501528.

Janzen DH. Seed predation by animals. Annual Review of Ecology and Systematics; 1971; 2: 465492.

Janzen DH, Miller GA, Jones JH, Pond CM, Hooper K, Janos DD. Two Costa Rican batgenerated seed shadows of Andira inermis

(Leguminosae). Ecology; 1976; 57: 501528.

Johns AD. Effects of selective timber extraction on rainforest structure and composition and some consequences for

frugivores and folivores. Biotropica; 1988; 20: 3137.

Kimmage K. Smallscale irrigation initiatives in Nigeria: the problems of equity and sustainability. Applied Geography; $1991 ; 11: 520$.

Lado C. Traditional agricultural land use and some changing trends in Maridi district, southern Sudan. Land Use Policy; $1989 ; 6: 324340$.

Lamprey $\mathrm{HE}$, et al. Report on the state of knowledge on browse in east Africa in 1980. In: Le Houerou (ed), Browse in Africa, ALCA Addis Ababa; 1980: 3354.

Lathrap DW. The house garden, a system of moderate instability, In: Our Father the Cayman, Our Mother the Gourd: Spinden Revisited, or a Unitary Model for the Emergence of Agriculture in the New World. The Hauge: Mouton; 1977.

Linares OF. "Garden Hunting" in the American Tropics. Human ECology; 1976; 4: 331349 .

Lundell CL. Plants probably utilized by the Old Empore Maya of Peten and adjacent lowlands. . Papers of the Michigan Academy of Science; 1938; 24: 3756 .

Lundell CL. The vegetation of the Peten. Carnegie Institution of Washington, Publication no. 478; 1937.

Maamun Y; Sarasutha IGP. Prospect of palm sago in Indonesia: South Sulawesi case study. Indonesian Agricultural Research and Development; 9: 52-56; 1987. 
MacClintock L; Whitcomb RF; Whitcomb BL. Island biogeography and 'habitat islands' of the eastern forest II. Evidence for the value of corridors and minimization of isolation in preservation of biotic diversity. American Birds; 1977; 31 : 612 .

Markley KS. The Babassu oil palm of Brazil. Economic Botany; $1971 ; 25: 267304$.

Martin SC. Values and uses for Mesquite. In: Management and Utilization of Arid Land Plants: Symposium Proceedings. Saltillo, Mexico: Rocky Mountain Forest and Range Experiement Station; 1985.

May PH, Anderson AB, Balick MJ, Frazao JMF. Subsistence benefits from the Babassu palm (Orbignya martiana). Economic Botany; 1985: 113129 .

McDonald CSA. Some ecological aspects of a nesting colony of heron. Ph.D. Dissertation, Auburn University, Auburn; 1971.

Mcdonnell MJ; Stiles EW. The structural complexity of old field vegetation and the recruitment of birddispersed plant species. oecologia; 1983; 56: 109116.

McNaughton SJ. Grassland herbivoir dynamics. In: Sinclair ARE, Nortongriffiths M, Serengeti: Dynamics of an Ecosystem; Chicago, Chicago University Press; 1979.

Miehe S. Acacia albida and other mutlipurpose trees on the Fur farmlands in the Jebel Marra highlands, Western Darfur, Sudan. Agroforestry Systems; 1986; 4: 89119.

Miksicek CH, Elsesser KJ, Wuebber IA, Bruhns KO, Hammond N. Rethinking ramon: a comment on Reina and Hill's lowland Maya subsistence. American Antiquity; 1981; 46: 916918.

Milne BT; Johnson KM; Forman RTT. Scaledependent proximity of wildlife habitat in a spatiallyneutral Bayesian model. Landscape Ecology; 1989.

Morril R, Gaile GL, Ghrall GI. Spatial Diffusion. Sage Publications, London. 
Nabhan BG; Sheridan TE. Living fencerows of the Rio San Miguel, Sonora, Mexico: Traditional technology for floodplain management. Human Ecology; 5: 97-111; 1977.

Netting RM. Maya subsistence: mythologies, analogies, possiblities. In: Adams REW (ed) The Origins of Maya Civilization, University of New Mexico Press, Albuquerque; 1977: 299333.

Norgaard RB. Sociosystem and ecosystem coevolution in the Amazon. Journal of Environmental Economics and Management; $1981 ; 8: 238254$.

National Research Council (NRC). Environmental change in the west African Sahel: resource management for arid and semiarid regions. National Academy Press, Washington; 1984.

Oba G. Perception of envionment among Kenyan pastoralists: implications for development. Nomadic Peoples; 1985; 19: 3357 .

Olsson K; Rapp A. Dryland degradation in central Sudan and conservation for survival. Ambio; 1991; 20: 192195.

Owen J. The medicosocial and cultural significance of Adansonia digitata (baobab) in African communities. African Notes; $1970 ; 6: 26-36$.

Palmeirim J, Etheridge $K$. The influence of manmade trails on foraging by tropical frugivorous bats. Biotropica; 1985; 17: 8283 .

Parker KW; Martin SC. The Mesquite Problem on Southern Arizona Ranges. US Department of Agriculture Circular 908, Washington DC; 1952 .

Peters CM. Brosinun alicastrum (Moraceae). Economic Botany; $1982 ; 36: 166175$.

Poschen P. An evaluation of the Acacia albidabased agroforestry practices in the Hararghe highlands of eastern Ethiopia. Agroforestry Systems; 1986; 4: 129143. 
Posey DA. Indigenous management of tropical forest ecosystems: the case of the Kayapo indians of the Brazilian Amazon. Agroforestry Systems; 1985; 3: 139158.

Puleston DE. Terracing, raised field and tree cropping in the Maya lowlands: a new perpective on the geography of power. In: Harrison PD, Turner II BL (eds.) PreHispanic Maya Agriculture, University of New Mexico Press, Albuquerque; 1978: 225245 .

Radwanski SA; Wickens GE. The ecology of Acacia albida on mantle soils in Zalingei, Jebel Marra, Sudan. Journal of Applied Ecology; 1967; 4: 569579.

Raintree JB. Strategies for enhancing the adoptability of agroforestry innovations. Agroforestry Systems; 1983; 1: 173187 .

Raintree JB; (ed.). Land, Trees and Tenure. Nairobi: ICRAF and the Land Tenure Center; 1987.

Reed CA. Origins of Agriculture. The Hague: Mouton Publishers; 1977.

Rindos D. Symbiosis, instability, and the origins and spread of agriculture: a new model. Current Anthropology; 1980; 21: 751772 .

Salem-Murdock M. The impact of agricultural development on a pastoral society: the Shukriya of the eastern Sudan. Institute for Developpment Anthropology Working Paper No. 17, Binghamton, New York; 1979: have.

Schoener TW. Models of optimal size for solitary predators. American Naturalist; 1969; 103: 277313.

Schwartz CC, Ellis JE. Feeding ecology and niche separation in some ungulates on the shortgrass prairie. Journal of Applied Ecology; 1981; 18: 343353 .

Senft RL, Rittenhouse LR, Woodmansee RG. Factors influencing patterns of grazing behavior on shortgrass steppe. Journal of Range Management; 1987; 38: 8187. 
Simoons JF. Northwest Ethiopia: Peoples and Economy. Madison, Wisconsin: University of Wisconsin Press; 1960.

Skarpe C. Structure of the woody vegetation in disturbed arid savanna, Bostwana. Vegetatio; 1990; 87: 1118.

Snedaker S. Successional immobilization of nutrients and biologically mediated recycling in tropical forests. Biotropica; 1980; 12: 1622 .

Somarriba E. Population dynamics of guava (Psidium guajava L.) in pastures. In: Beer JW, Fassbender HW, Hueveldop J (eds.) Advances in Agroforestry Research, Proceedings of a Seminar, Turrialba, Costa Rica; 1987.

Taylor GF, Soumare M. Strategies of forestry development in the semiarid tropics: lessons from the Sahel. In: Wiersum KF (ed.) Strategies and Designs for Afforestation, Reforestation, and Tree Planting. Wageningen: Pudoc; 1983.

Thomas DW, Cloutier D, Provencher M, Houle C. The shape of bird and batgenerated seed shadows around a tropical fruiting tree. Biotropica; 1988; 20: 347348.

Townsend PK. Sago production in a New Guinea economy. Human ECology; 1974; 2: 217236.

Turner BL; Miksicek CH. Economic plant species associated with prehistoric agriculture in the Maya lowlands. Economic Botany; 1984; 38: 179193.

Turner MG. Landscape ecology: the effect of pattern on process. Annual Review of Ecology and Systematics; 1989; 20: 171197.

Tuttle MD. Collecting techniques. In: Baker RJ, Jones JK jr, Carter Dc (eds.) Biology of the New world family Phyllostomatidae Par I. Special Publications of the Museum, Texas Tech Press, Lubbock; 1976: 7188.

Unruh JD. Ecological aspects of site recovery under swidden fallow management in the Peruvian Amazon. Agroforestry Systems; 1988; 7: 161184. 
Unruh JD. Iterative Increase of economic tree species in managed swidden fallows of the Amazon. Agroforestry Systems; 1990; 11: 175197 .

Unruh JD. An Acacia-based design for sustainable livestock carrying capacity on irrigated farmlands in semi-arid Africa. Ecological Engineering; 1993; 2: 131-148

Valentine KA; Gerard JB. LifeHistory characteristics of the creasotebush, Larrea tridentata. New Mexico Agricultural Experiment Station Bulletin 526, Las Cruces; 1968.

White S. Cedar and mahogany logging in eastern Peru. The Geographical Review; 1975; 394-416.

Wickens GE. The uses of baobab (Adansonia Digitata L.) in Africa. In: Le Houerou HN (ed.) Browse in Africa. ILCA, Addis Ababa; 1980 .

Winterbottom R; Hazlewood T. Agroforestry and sustainable development: making the connection. Ambio; 1978; 16: 100110.

Woodmansee RG. Factors influenceing input and output of nitrogen in grasslands. In: French NR (ed.) Perspectives in Grassland Ecology; 1979; New York, Springer Verlag.

Yen DE. Aboriculture in the subsistence of Santa Cruz, Soloman Islands. Economic Botany; 28: 247-284; 1974.

Young A. Agroforestry and its potential to contribute to land development in the tropics. Journal of Biogeography; 1988; 15: 1930 . 


\section{Appendix \\ List of Species and Land-Uses Where Evidence Exists for their Diffusion via Land Use*}

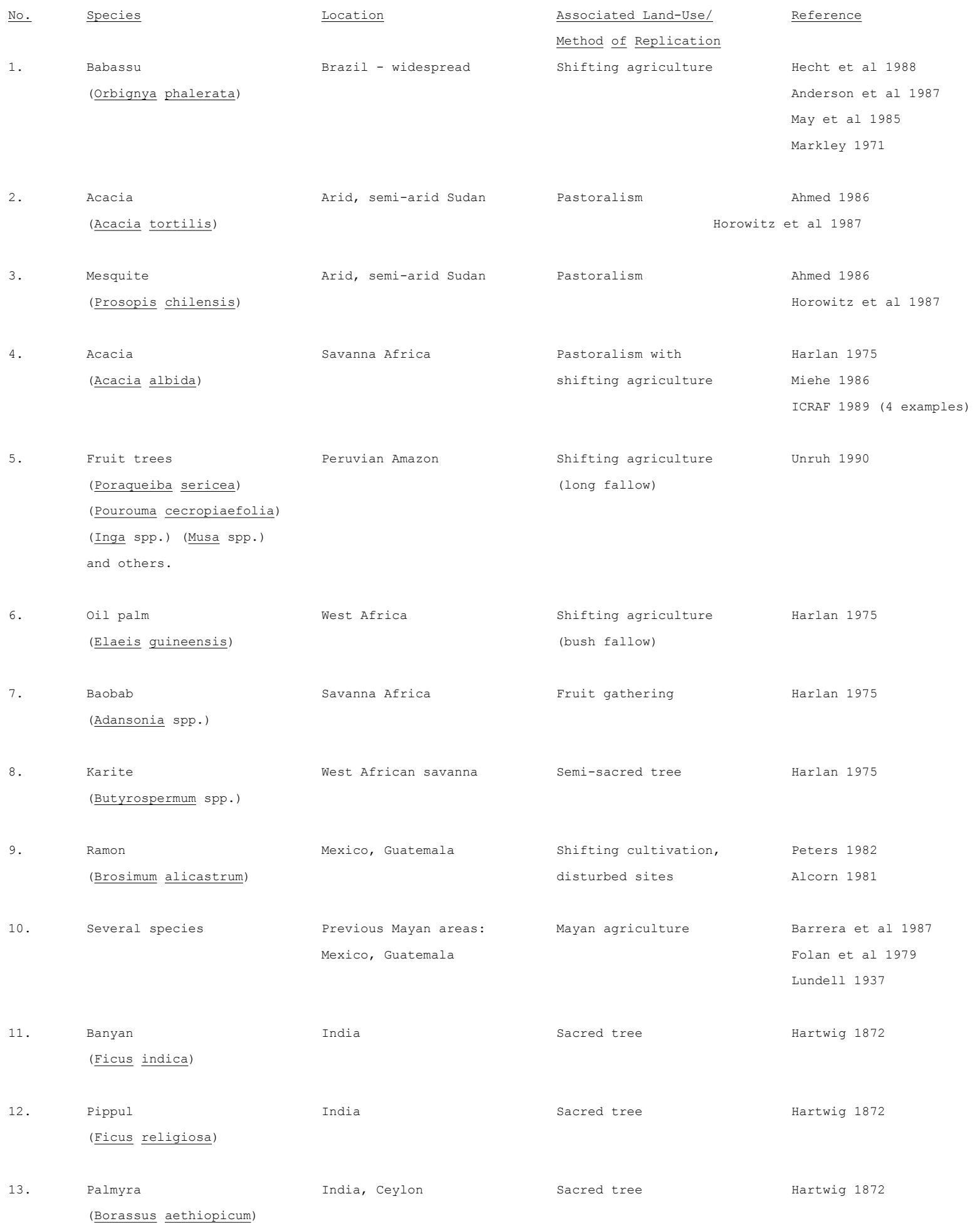




\begin{tabular}{|c|c|c|c|c|}
\hline 14. & $\begin{array}{l}\text { Date palms } \\
\text { (Palmae numerous species) }\end{array}$ & North Africa, Middle East & Sacred tree & Hartwig 1872 \\
\hline 15. & (Cordia abyssinica) & Sudan & $\begin{array}{l}\text { Birds \& human consumption } \\
\text { of fruits }\end{array}$ & Hartwig 1872 \\
\hline 16. & (Ziziphus spina-christi) & Sudan & $\begin{array}{l}\text { Birds \& human consumption } \\
\text { of fruits }\end{array}$ & Hartwig 1872 \\
\hline 17. & (Ficus thonningii) & Sudan & $\begin{array}{l}\text { Epiphytic germination on } \\
\underline{\text { Acacia albida } \& \text { Cordia }} \\
\text { abyssinica }\end{array}$ & Miehe 1975 \\
\hline 18. & $\begin{array}{l}\text { Spanish Cedar } \\
\text { (Cedrela odorata) }\end{array}$ & Eastern Peru & $\begin{array}{l}\text { Shifting agriculture, } \\
\text { logging }\end{array}$ & White 1975 \\
\hline 19. & $\begin{array}{l}\text { Mahogany } \\
\text { (Swietenia macrophylla) }\end{array}$ & Eastern Peru & $\begin{array}{l}\text { Shifting agriculture } \\
\text { logging }\end{array}$ & White 1975 \\
\hline 20. & $\begin{array}{l}\text { Neem } \\
\text { (Azadirachta indica) }\end{array}$ & Sahelian Africa & $\begin{array}{l}\text { Valued tree, spread by } \\
\text { birds and bats }\end{array}$ & Taylor et al 1983 \\
\hline 21. & $\begin{array}{l}\text { Mamey } \\
\text { (Calocarpum mammosum) }\end{array}$ & Yucatan Mexico & $\begin{array}{l}\text { Maintained on its own } \\
\text { after Mayan utilization }\end{array}$ & Lundell 1938 \\
\hline 22. & $\begin{array}{l}\text { Zapote } \\
\text { (Achras zapota) }\end{array}$ & Yucatan Mexico & $\begin{array}{l}\text { Replicates in swidden } \\
\text { fallows }\end{array}$ & $\begin{array}{l}\text { Lundell } 1938 \\
\text { Budowski } 1959\end{array}$ \\
\hline 23. & $\begin{array}{l}\text { Guayo } \\
\text { (Talisia olivaeformis) }\end{array}$ & Yucatan Mexico & $\begin{array}{l}\text { Maintained on its own } \\
\text { after Mayan utilization }\end{array}$ & Lundel1 1938 \\
\hline 24 . & $\begin{array}{l}\text { Custard apple } \\
\text { (Annona reticulata) }\end{array}$ & Yucatan Mexico & $\begin{array}{l}\text { Maintained on its own } \\
\text { after Mayan utilization }\end{array}$ & Lundell 1938 \\
\hline 25. & $\begin{array}{l}\text { Sago palm } \\
\text { (Metroxylon sagu) }\end{array}$ & Indonesia & $\begin{array}{l}\text { Increased recognition and } \\
\text { utilization/encouragement } \\
\text { with constraints on } \\
\text { shifting agriculture }\end{array}$ & $\begin{array}{l}\text { Harlan } 1975 \\
\text { Ellen } 1979 \\
\text { Yen } 1974 \\
\text { Maamun } 1987\end{array}$ \\
\hline 26. & $\begin{array}{l}\text { Acacia } \\
\text { (Acacia senegal) }\end{array}$ & Arid, semi-arid Sudan & Pastoralism & $\begin{array}{l}\text { Ahmed } 1986 \\
\text { Horowitz et al } 1987\end{array}$ \\
\hline 27. & $\begin{array}{l}\text { Nere } \\
\text { (Parkia biglobosa) }\end{array}$ & West Africa & Shifting agriculture & Houerou 1980 \\
\hline 28. & $\begin{array}{l}\text { Several tree species } \\
\text { native to Niger }\end{array}$ & Niger & $\begin{array}{l}\text { Small earthen landscape } \\
\text { structures to divert } \\
\text { water onto slopes }\end{array}$ & Harrison 1987 \\
\hline
\end{tabular}




\begin{tabular}{|c|c|c|c|c|}
\hline 29. & Riparian woody growth & New Mexico, USA & $\begin{array}{l}\text { Irrigation canals and living } \\
\text { fencerows around field } \\
\text { allows extension of } \\
\text { woody growth. }\end{array}$ & $\begin{array}{l}\text { Emslie } 1981 \\
\text { Nabhan } 1977 \\
\text { ICRAF } 1989 \text { ( } 2 \text { examples) }\end{array}$ \\
\hline 30. & $\begin{array}{l}\text { Lontar palm } \\
\text { (Borassus flabellifer) }\end{array}$ & Indonesia & $\begin{array}{l}\text { Degraded shifting } \\
\text { agriculture }\end{array}$ & Fox 1977 \\
\hline 31. & $\begin{array}{l}\text { Guava } \\
\text { (Psidium guajava) }\end{array}$ & Costa Rica & $\begin{array}{l}\text { Pasture lands, } \\
\text { dispersed by cattle }\end{array}$ & Somarriba 1987 \\
\hline 32 . & $\begin{array}{l}\text { Acacia } \\
\text { (Acacia senegal) }\end{array}$ & Arid, semi-arid Sudan & $\begin{array}{l}\text { Colonizes fallow of } \\
\text { shifting agriculture }\end{array}$ & Abdul 1987 \\
\hline 33. & $\begin{array}{l}\text { Laurel } \\
\text { (Cordia alliodora) }\end{array}$ & Tabasco, Mexico & $\begin{array}{l}\text { Associated with } \\
\text { pastures }\end{array}$ & ICRAF 1989 \\
\hline 34 . & $\begin{array}{l}\text { Mango } \\
\text { (Mangifera indica) }\end{array}$ & Tabasco, Mexico & $\begin{array}{l}\text { Associated with } \\
\text { pastures }\end{array}$ & ICRAF 1989 \\
\hline 35. & $\begin{array}{l}\text { Citrus } \\
\text { (Citrus sinensis) }\end{array}$ & Tabasco, Mexico & $\begin{array}{l}\text { Associated with } \\
\text { pastures }\end{array}$ & ICRAF 1989 \\
\hline 36. & Several tree species & Western Nepal & Hill farms & ICRAF 1989 \\
\hline 37. & $\begin{array}{l}\text { Spanish Cedar } \\
\text { (Cedrela odorata) }\end{array}$ & Merida, Venezuela & $\begin{array}{l}\text { Associated with } \\
\text { pastures }\end{array}$ & ICRAF 1989 \\
\hline 38. & (Tabebuia $\underline{\text { rosae) }}$ & Merida, Venezuela & $\begin{array}{l}\text { Associated with } \\
\text { pastures }\end{array}$ & ICRAF 1989 \\
\hline 39. & (Triplaris meridansis) & Merida, Venezuela & $\begin{array}{l}\text { Associated with } \\
\text { pastures }\end{array}$ & ICRAF 1989 \\
\hline
\end{tabular}

*Note: Some species may be listed more than once if they are spread by different land-uses, or if they are spread by different ways via the same land-use in different locations. 


\section{Caption for Figure}

Figure 1. Intermediate states between crops and weeds. Adapted from Harlan (1975) and Alcorn (1981). 


\section{Figure 1.}

Ecological Adaptation:

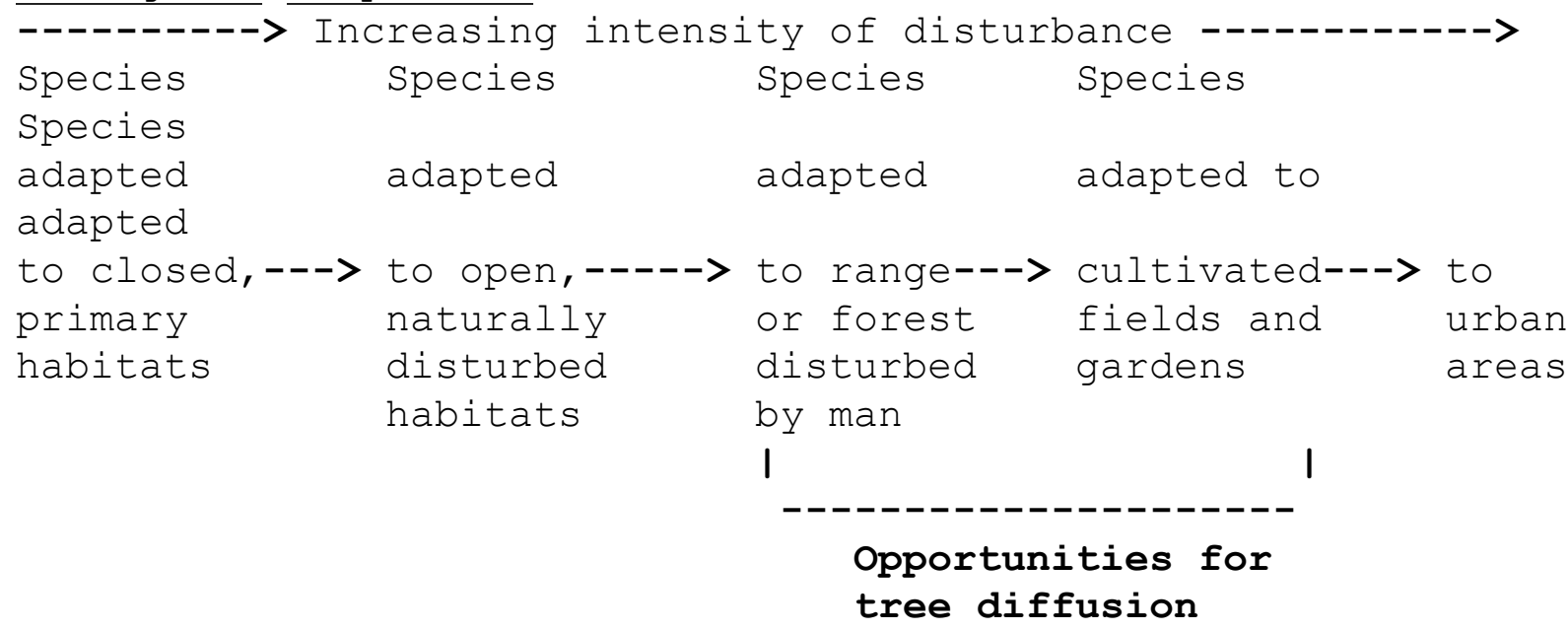

Human Response:

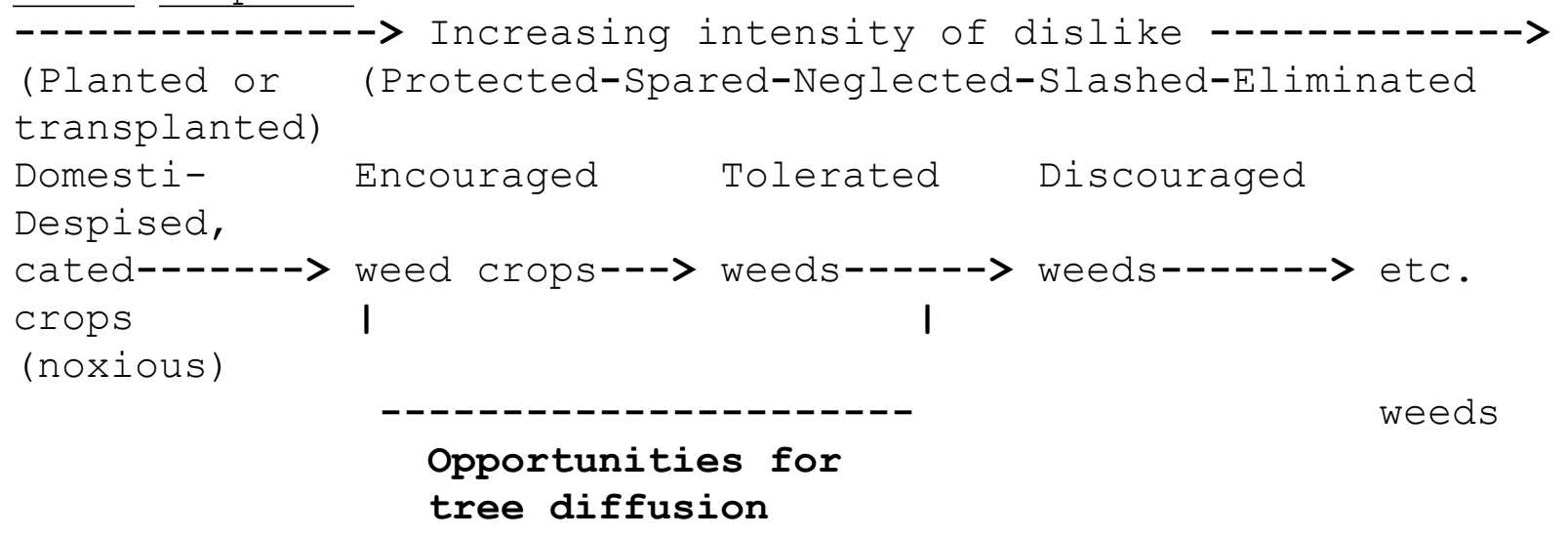

